\title{
AKUNTABILITAS PENGELOLAAN ALOKASI DANA DESA (ADD) DI DESA PANGGUNGREJO, KECAMATAN KEPANJEN, KABUPATEN MALANG
}

\author{
Firsttantri Izza Aryanti ${ }^{1 *}$, Dessy Putri Andini ${ }^{1}$ \\ ${ }^{1}$ Politeknik Negeri Jember, Jl. Mastrip No.164 Jember, Indonesia \\ Korespondensi: izzaaryanti@gmail.com
}

\begin{abstract}
This study aims to measure the application of the principle of accountability carried out by the Panggungrejo Village Government, Kepanjen District, Malang Regency in the management of Village Fund Allocation. This study used qualitative methods with data collection techniques used in the form of open interviews which were then followed by data validity testing using triangulation techniques. The results showed that all stages of Village Fund Allocation management carried out by the Panggungrejo Village Government had implemented the principle of accountability although there were obstacles experienced at the implementation stage, the cause of which was the delay in disbursing funds from the Malang Regency Government. Even so, the Panggungrejo Village Government has succeeded in implementing all indicators of conformity according to Peraturan Bupati Malang Nomor 35 Tahun 2017 at each stage.
\end{abstract}

Keywords: Accountability, Village Fund Allocation, Village Government

\begin{abstract}
ABSTRAK
Penelitian ini bertujuan untuk mengukur penerapan prinsip akuntabilitas yang dilakukan Pemerintah Desa Panggungrejo, Kecamatan Kepanjen, Kabupaten Malang dalam pengelolaan Alokasi Dana Desa. Penelitian ini menggunakan metode kualitatif dengan teknik pengumpulan data yang digunakan berupa wawancara terbuka yang kemudian dilanjutkan dengan uji keabsahan data menggunakan teknik triangulasi. Hasil penelitian menunjukkan bahwa seluruh tahap pengelolaan Alokasi Dana Desa yang dilaksanakan oleh Pemerintah Desa Panggungrejo telah menerapkan prinsip akuntabilitas walaupun terdapat kendala yang dialami pada tahap pelaksanaan yang diketahui penyebabnya adalah keterlambatan pencairan dana dari Pemerintah Kabupaten Malang. Meskipun demikian, Pemerintah Desa Panggungrejo telah berhasil melaksanakan seluruh indikator kesesuaian menurut Peraturan Bupati Malang Nomor 35 Tahun 2017 di setiap tahapannya.
\end{abstract}

Kata kunci: Akuntabilitas, Alokasi Dana Desa, Pemerintah Desa. 


\section{PENDAHULUAN}

Keberadaan desa telah ditetapkan menjadi salah satu fokus penting dalam pembangunan nasional. Hal tersebut dilakukan dengan tujuan agar ketimpangan pembangunan antara desa dan kota dapat diminimalisir. Hal tersebut dijelaskan dalam Undang-Undang Nomor 6 Tahun 2014 yang menjelaskan bahwa desa diberikan otonomi seluas-luasnya untuk mengatur urusan pemerintahannya di luar urusan pemerintah yang ditetapkan dalam Undang-Undang. Pemberian otonomi tersebut dikarenakan keberadaan desa yang memiliki peran strategis yang langsung berhadapan dengan masyarakat luas dengan berbagai latar belakang, menaruh harapan agar hasil yang telah dicapai dapat langsung menyentuh kepentingan masyarakat sehingga tercipta kesejahteraan masyarakat yang lebih merata (Fajri et al., 2015).

Dalam rangka merealisasikan tujuan tersebut, pemerintah mengeluarkan kebijakan bantuan dana yang disebut Alokasi Dana Desa (ADD) untuk kemudian disalurkan kepada desa berupa dana transfer yang berasal dari dana perimbangan keuangan pemerintah pusat dan pemerintah daerah yang diterima oleh kabupaten/kota (Putra et al., 2017). Pemberian ADD merupakan bentuk dukungan dalam rangka mewujudkan tujuan ADD yakni mendorong semangat desentralisasi menuju desa yang maju, mandiri, dan demokratis dengan berlandaskan prinsip adil, transparan, dan akuntabel. Terlaksananya beberapa prinsip tersebut diharapkan dapat tercipta pengelolaan dan pelaksanaan ADD yang taat, sehingga mampu merealisasikan aspek tata kelola keuangan desa yang lebih baik.

Akuntabilitas adalah salah satu aspek pendukung atas terciptanya tata kelola keuangan desa yang baik (Andini \& Ahmad, 2021; Astuti \& Yulianto, 2016). Akuntabilitas merupakan bentuk pertanggungjawaban atas pelaksanaan misi organisasi melalui media akuntabilitas untuk mencapai tujuan yang telah ditetapkan (Putra et al., 2017). Akuntabilitas menjadi indikator penting pemerintahan untuk mendapatkan kepercayaan masyarakat dan menjadi tolok ukur dari kuat atau lemahnya partisipasi masyarakat (Kholmi, M., 2017). Akuntabilitas dalam keuangan pemerintah desa merupakan kewajiban melaporkan dan mempertanggungjawabkan dana desa secara vertikal kepada pemerintah kabupaten/kota dan secara horizontal kepada masyarakat atas perencanaan, pelaksanaan, dan penatausahaan secara berkala (Imawan et al., 2019). Keberhasilan atau kegagalan akuntabilitas keuangan atas tata kelola dana desa oleh pemerintah desa diukur dari kepatuhan dan ketaatan terhadap asas partisipatif, akuntabel, transparan, tertib, dan disiplin yang kemudian digunakan sebagai cerminan kepatuhan dan ketaatan pemerintah desa terhadap peraturan yang berlaku (Febri Arifiyanto \& Kurrohman, 2014). Desa

Panggungrejo Kecamatan Kepanjen, merupakan salah satu desa berprestasi di Kabupaten Malang dan beberapa kali ditunjuk sebagai desa percontohan dalam hal pelaksanaan tata kelola keuangan dan administrasi desa. Berdasar prestasi tersebut, peneliti tertarik untuk mengetahui lebih dalam mengenai pengelolaan keuangan desa pada pos anggaran Alokasi Dana Desa (ADD) di Desa Panggungrejo yang dalam pelaksanaannya dibagi menjadi 3 (tiga) tahap antara lain tahap perencanaan, pelaksanaan, pelaporan, dan pertanggungjawaban yang berpedoman pada Peraturan Bupati (Perbup) Malang Nomor 35 Tahun 2017 tentang Pedoman Pelaksanaan Alokasi Dana Desa. Pada masing-masing tahapan, menurut Perbup dijelaskan bahwa terdapat indikator keberhasilan yang menjadi tolok ukur keberhasilan terlaksananya prinsip akuntabilitas. Berdasarkan latar belakang di atas, penelitian ini akan mengukur penerapan prinsip akuntabilitas pengelolaan ADD di Desa Panggungrejo Kecamatan Kepanjen Kabupaten Malang dengan acuan indikator keberhasilan pada masingmasing tahapan yang kemudian disesuaikan dengan Peraturan Bupati (Perbup) Malang Nomor 35 Tahun 2017. 


\section{METODE PENELITIAN}

Penelitian ini termasuk penelitian kualitatif dengan sifat penelitian model interaktif yang difokuskan pada latar tempat yang dipilih sebagai subjek penelitian menggunakan purposive sampling dengan kriteria sampel yang ditetapkan antara lain : (1) Pemerintah desa selaku tim pelaksana desa yang terlibat dalam pelaksanaan pengelolaan Alokasi Dana Desa, antara lain Kepala Urusan (Kaur) Perencanaan, Kaur Keuangan, Kepala Desa, dan Sekretaris Desa, serta (2) Tokoh masyarakat sebanyak 1 (satu) orang dan 2 (dua) orang warga desa yang terlibat dan mengetahui langsung pada tahapan pengelolaan Alokasi Dana Desa (ADD) di Desa Panggungrejo.

Beberapa informan diatas dipilih untuk menjadi sampel dalam pengujian keabsahan yang dilakukan menggunakan triangulasi. Pengumpulan data yang diperoleh dengan cara observasi, wawancara, dan juga studi dokumentasi yang selanjutnya dilakukan analisis data dengan tahapan pengumpulan data, pengujian data, pengkodean, reduksi data, display data, serta verifikasi data, dan kemudian penarikan kesimpulan dari data yang diperoleh sehingga menggambarkan ciri, karakter, sifat, dan model dari fenomena tersebut

\section{HASIL DAN PEMBAHASAN}

\section{Pengelolaan Alokasi Dana Desa (ADD) di Desa Panggungrejo}

Pengelolaan ADD di Desa Panggungrejo dilaksanakan melalui tahap perencanaan, pelaksanaan, dan pertanggungjawaban yang berlandaskan pada Peraturan Bupati Malang Nomor 35 Tahun 2017. Penggunaan ADD yang diterima, digunakan untuk membiayai dua komponen dengan masing-masing pagu pada tiap komponen yakni, (1) Sebesar 70\% digunakan untuk membiayai pemberdayaan masyarakat dan pembangunan desa, (2) Sebesar 30\% digunakan untuk membiayai operasional Pemerintahan Desa dan Badan Permusyawaratan Desa. Berikut ini adalah program kerja yang dibiayai dengan Alokasi Dana Desa tahun 2019.

Tabel 1. Program Kegiatan ADD di Desa Panggungrejo TA 2019

\begin{tabular}{lccc}
\hline NO & NAMA KEGIATAN & $\begin{array}{c}\text { ANGGARAN } \\
(\mathrm{Rp})\end{array}$ & SUMBER DANA \\
\hline
\end{tabular}

\section{A. BIDANG PENYELENGGARAAN PEMERINTAH DESA}

1 Penyediaaan Penghasilan Tetap dan

Tunjangan Kepala Desa

40.320 .000

$\mathrm{ADD}$

2 Penyediaaan Penghasilan Tetap dan

Tunjangan Perangkat Desa

160.320 .000

ADD

Penyediaan Jaminan Sosial Bagi Kepala

3 Desa dan Perangkat Desa (BPJS

21.168.000

ADD

Ketenagakerjaan)

Penyediaan Operasional Pemerintah

4 Desa (ATK, Honor PKPKD dan PPKD dll)

5 Penyediaan Tunjangan BPD

99.016 .602

ADD

6 Penyediaan Operasional BPD

34.800 .000

ADD

7 Penyediaan Insentif RT/RW

2.000 .000

ADD

52.884 .000

ADD, PAD

$9 \quad$ Penyediaan Sarana (Aset Tetap)

Perkantoran / Pemerintahan

26.550 .000

ADD 


\begin{tabular}{|c|c|c|c|}
\hline \multicolumn{4}{|c|}{ B. BIDANG PEMBINAAN KEMASYARAKATAN } \\
\hline 1 & $\begin{array}{l}\text { Penguatan \& Peningkatan Kapasitas } \\
\text { Tenaga Keamanan/Ketertiban oleh } \\
\text { Pemdes (Kegiatan Pembinaan } \\
\text { Keamanan dan Ketertiban) }\end{array}$ & 23.200 .000 & $\mathrm{ADD}$ \\
\hline 2 & $\begin{array}{l}\text { Penyelenggaraan Festival Kesenian, } \\
\text { Adat/Kebudayaan dan Keagamaan } \\
\text { (HUT RI, Raya Keagamaan dll) } \\
\text { (Kegiatan PPHBI) }\end{array}$ & 5.875 .000 & $\mathrm{ADD}$ \\
\hline 3 & Bantuan untuk Tempat Ibadah & 30.750 .000 & $\mathrm{ADD}$ \\
\hline 4 & $\begin{array}{l}\text { Penyelenggaraan Pelatihan } \\
\text { Kepemudaan Tingkat Desa }\end{array}$ & 15.000 .000 & $\mathrm{ADD}$ \\
\hline 5 & Pembinaan LPMD & 6.560 .000 & $\mathrm{ADD}$ \\
\hline 6 & Pembinaan PKK & 46.656 .000 & ADD \\
\hline
\end{tabular}

Sumber : RKPDesa Panggungrejo tahun 2019

\section{Akuntabilitas Pengelolaan ADD}

Akuntabilitas merupakan suatu pertanggungjawaban yang harus dilaksanakan oleh pihak-pihak tertentu mengenai kepercayaan yang telah diberikan masyarakat maupun individu dalam hal berhasil atau tidaknya suatu pelaksanaan tugas ditunaikan sesuai ketentuan yang berlaku. Pertanggungjawaban tersebut erat kaitannya dengan proses birokrasi yang dalam hal ini adalah pemberian pelayanan sebagai hubungan timbal balik atas hak dan kewajiban dari masyarakat yang telah dipungut secara langsung maupun tidak langsung. Pertanggungjawaban dilakukan melalui media yang kemudian disampaikan kepada pihak internal maupun eksternal secara berkala maupun tak terduga sebagai suatu kewajiban atas dasar hukum dan bukan karena sukarela.

Tabel 2. Indikator Kesesuaian Akuntabilitas Perencanaan Menurut Peraturan Bupati Malang Nomor 35 Tahun 2017

\begin{tabular}{|c|c|c|c|}
\hline No. & Indikator Kesesuaian & Hasil Wawancara & Ket \\
\hline 1. & $\begin{array}{l}\text { Proses perencanaan diawali } \\
\text { dengan Musyawarah Desa yang } \\
\text { merupakan forum pertemuan } \\
\text { musyawarah dan pimpinan oleh } \\
\text { Kepala Desa untuk membahas } \\
\text { perencanaan APBDesa serta } \\
\text { RKPDesa. }\end{array}$ & $\begin{array}{l}\text { Perencanaan } \text { ADD Desa } \\
\text { Panggungrejo telah diawali } \\
\text { dengan pelaksanaan } \\
\text { Musyawarah Desa. }\end{array}$ & Sesuai \\
\hline 2. & $\begin{array}{l}\text { Musyawarah Desa dihadiri oleh } \\
\text { Kepala Desa, Perangkat Desa, } \\
\text { anggota } \\
\text { Permusyawaratan Badan } \\
\text { Lembaga Kemasyarakatan, dan } \\
\text { Tokoh Masyarakat. }\end{array}$ & $\begin{array}{l}\text { Musyawarah Desa } \\
\text { Panggungrejo telah dihadiri } \\
\text { Kepala Desa, Perangkat Desa, } \\
\text { anggota Badan } \\
\text { Permusyawaratan Desa, } \\
\text { Lembaga Kemasyarakatan, } \\
\text { dan Tokoh Masyarakat. }\end{array}$ & Sesuai \\
\hline 3. & $\begin{array}{l}\text { Hasil Musyawarah Desa } \\
\text { dituangkan dalam Berita Acara } \\
\text { Pelaksanaan Musyawarah Desa. }\end{array}$ & $\begin{array}{lr}\text { Hasil Musyawarah } & \text { Desa } \\
\text { Panggungrejo } & \text { telah } \\
\text { dituangkan dalam } & \text { Berita } \\
\text { Acara } & \text { Pelaksanaan } \\
\text { Musyawarah Desa }\end{array}$ & Sesuai \\
\hline
\end{tabular}

Akuntabilitas pengelolaan ADD di Desa Panggungrejo, dilakukan dengan adanya pertanggungjawaban pada seluruh pelaksanaan program dan kegiatan pada masing-masing tahap baik secara teknis maupun 
hukum. Berikut indikator kesesuaian akuntabilitas pada masing-masing tahapan menurut Perbup Malang Nomor 35 Tahun 2017 yang kemudian telah diringkas dan disesuaikan dengan hasil wawancara, hasil observasi, dan studi dokumentasi yang telah dilaksanakan selama penelitian.

Tabel 3. Indikator Kesesuaian Akuntabilitas Pelaksanaan Menurut Peraturan Bupati Malang Nomor 35 Tahun 2017

\begin{tabular}{|c|c|c|c|}
\hline No. & Indikator Kesesuaian & Hasil Wawancara & Ket \\
\hline 1. & $\begin{array}{l}\text { Setelah dana Alokasi Dana Desa } \\
\text { masuk ke dalam Rekening Kas } \\
\text { Desa, Kepala Desa mengadakan } \\
\text { rapat di Desa yang dihadiri oleh } \\
\text { Perangkat Desa, anggota Badan } \\
\text { Permusyawaratan Desa, } \\
\text { Lembaga Kemasyarakatan, dan } \\
\text { Tokoh Masyarakat. }\end{array}$ & $\begin{array}{l}\text { Kepala Desa Panggungrejo } \\
\text { telah mengadakan rapat di } \\
\text { Desa untuk membahas } \\
\text { pelaksanana kegiatan dan } \\
\text { penjadwalan serta pembagian } \\
\text { tugas para pelaksana kegiatan } \\
\text { dalam hal pelaksanaan } \\
\text { Alokasi Dana Desa. }\end{array}$ & Sesuai \\
\hline 2. & $\begin{array}{lr}\text { Dalam pelaksanaan } & \begin{array}{r}\text { kegiatan } \\
\text { dengan }\end{array} \\
\text { dilakukan } & \text { tenaga } \\
\text { memanfaatkan } & \text { masyarakat desa setempat } \\
\text { untuk pekerjaan yang } \\
\text { memerlukan tenaga mereka. }\end{array}$ & $\begin{array}{lr}\text { Pelaksanaan program dan } \\
\text { kegiatan di } & \text { Desa } \\
\text { Panggungrejo } & \text { telah } \\
\text { memanfaatkan } & \text { tenaga } \\
\text { masyarakat desa setempat } \\
\text { dengan membentuk panitia } \\
\text { lokal. }\end{array}$ & Sesuai \\
\hline 3. & $\begin{array}{l}\text { Selama pelaksanaan kegiatan, } \\
\text { perlu adanya dokumentasi } \\
\text { kegiatan sejak awal sebelum } \\
\text { kegiatan dilaksanakan, pada saat } \\
\text { pelaksanaan, dan akhir } \\
\text { pelaksanaan kegiatan }\end{array}$ & $\begin{array}{lr}\text { Seluruh pelaksanaan program } \\
\text { dan kegiatan di } & \text { Desa } \\
\text { Panggungrejo telah dilakukan } \\
\text { dokumentasi dari } & \text { awal } \\
\text { pelaksanaan hingga akhir } \\
\text { pelaksanaan. }\end{array}$ & Sesuai \\
\hline
\end{tabular}

Tabel 4. Indikator Kesesuaian Akuntabilitas Pertanggungjawaban Menurut Peraturan Bupati Malang Nomor 35 Tahun 2017

\begin{tabular}{|c|c|c|c|}
\hline No. & Indikator Kesesuaian & Hasil Wawancara & Ket \\
\hline 1 . & $\begin{array}{l}\text { Para pelaksana kegiatan } \\
\text { membuat } \\
\text { pertanggungjawaban kepada } \\
\text { Pelaksana Teknis Pengelolaan } \\
\text { Keuangan Desa (PTPKD). }\end{array}$ & $\begin{array}{l}\text { Pelaksana kegiatan telah } \\
\text { membuat pertanggungjawaban } \\
\text { kepada PTPKD. }\end{array}$ & Sesuai \\
\hline 2. & $\begin{array}{l}\text { PTPKD menghimpun seluruh } \\
\text { pertanggungjawaban dari } \\
\text { pelaksana kegiatan untuk } \\
\text { membuat } \\
\text { pertanggungjawaban kepada } \\
\text { Bupati melalui Camat dalam } \\
\text { bentuk rekapitulasi ke Dinas } \\
\text { Pemberdayaan Masyarakat } \\
\text { dan Desa. }\end{array}$ & $\begin{array}{l}\text { PTPKD Desa Panggungrejo telah } \\
\text { membuat pertanggungjawaban } \\
\text { kepada Bupati melalui Camat } \\
\text { dalam bentuk rekapitulasi ke } \\
\text { Dinas Pemberdayaan Masyarakat } \\
\text { dan Desa. }\end{array}$ & Sesuai \\
\hline 3. & $\begin{array}{l}\text { Kepala Desa menyampaikan } \\
\text { laporan pertanggungjawaban } \\
\text { kepada Dinas Pemberdayaan } \\
\text { Masyarakat dan Desa melalui } \\
\text { Camat. }\end{array}$ & $\begin{array}{l}\text { Kepala Desa Panggungrejo telah } \\
\text { menyampaikan laporan } \\
\text { pertanggungjawaban kepada } \\
\text { Dinas Pemberdayaan Masyarakat } \\
\text { dan Desa melalui Camat. }\end{array}$ & Sesuai \\
\hline
\end{tabular}

\section{Perencanaan}

Tahap perencanaan ADD Desa Panggungrejo diawali dengan dilaksanakannya Musyawarah Dusun (Musdus) pada masing-masing dusun untuk mendapatkan hasil yang kemudian akan dibahas pada Musyawarah Desa (Musdes). Pemberian kebijakan 
dilaksanakannya musdus bertujuan agar penyerapan aspirasi warga dapat dilakukan dengan maksimal sehingga dapat menyusun program dan kegiatan sesuai dengan kebutuhan masyarakat. Hal tersebut dijelaskan oleh Sekretaris Desa Panggungrejo:

"untuk regulasinya ini kami mengacu pada Permendagri 113/2014. Dari tahap awal, di tahap perencanaan sampai nanti pelaporan untuk pertanggungjawaban harus sesuai regulasi. Namun untuk spesifikasi terkait pedoman khusus pengelolaan ADD, kita mengacu pada Perbup. Untuk bagaimana teknisnya itu, kita ada rapat RT RW kemudian ada Musdus yaitu Musyawarah di masing-masing dusun untuk kemudian dibahas di Musdes." (Sekretaris Desa Panggungrejo)

Didukung juga oleh hasil wawancara dengan Kaur Keuangan Desa Panggungrejo, yang menjelaskan:

"regulasinya pakai Perbup pedoman pelaksanaan ADD. Kalau tahapannya dimulai dari Musdes untuk membahas anggaran dan program kegiatan yang akan dilaksanakan. Kalau musyawarah sudah mufakat mengenai anggaran dan program kegiatan yang dilaksanakan, nanti di akhir musdes dicatat hasil musyawarah di berita acara untuk nanti disetujui pak Kades dan BPD selanjutnya ditetapkan melalui Perdes baru bisa dilaksanakan programnya." (Kaur Keuangan Desa Panggungrejo)

Pembahasan hasil Musdus akan dijabarkan di dalam pelaksanaan Musdes untuk kemudian dilakukan pengkajian untuk menentukan skala prioritas dari program dan kegiatan yang diusulkan. Musdes dihadiri oleh kepala desa beserta perangkat desa, anggota Badan Permusyawaratan Desa (BPD), tokoh masyarakat, dan lembaga kemasyarakatan. Sasaran dalam pelaksanaan Musdes adalah membahas mengenai penyusunan rencana keuangan tahunan pemerintahan desa yang didalamnya juga termasuk pos anggaran dana Alokasi Dana Desa (ADD). Hasil Musdes akan dituangkan ke dalam berita acara pelaksanaan Musdes yang selanjutnya akan dibahas dan disetujui oleh Pemerintah Desa dan BPD untuk ditetapkan melalui Peraturan Desa (Perdes) dan kemudian dapat digunakan sebagai dasar pelaksanaan ADD.

Hasil wawancara diatas menunjukkan bahwa dalam hal perencanaan, Pemerintah Desa Panggungrejo telah mengimplementasikan prinsip akuntabilitas. Penjelasan yang didapat dari tokoh masyarakat dan warga desa juga dapat disesuaikan dengan pernyataan dari kepala desa yang mengacu pada pedoman perencanaan yang dimuat pada Peraturan Bupati Malang Nomor 35 Tahun 2017. Berdasarkan hasil penelitian diatas, tahap perencanaan ADD Desa Panggungrejo dapat dikatakan akuntabel dapat disesuaikan dengan Peraturan Bupati Malang Nomor 35 Tahun 2017 tentang Pedoman Pelaksanaan Alokasi Dana Desa.

\section{Pelaksanaan}

Pada tahap pelaksanaan ADD, Pemerintah Desa Panggungrejo membagi menjadi 2 (dua) tahap yakni tahap proses pencairan dana dan pelaksanaan kegiatan. Pada proses pencairan dana dilaksanakan dengan mengajukan pencairan dana yang dikirim oleh Dinas Pemberdayaan Masyarakat dan Desa (DPMD) kepada Badan Pengelolaan Keuangan dan Aset Daerah (BPKAD).

Kepala Urusan (Kaur) Keuangan Desa Panggungrejo menjelaskan tidak adanya kendala serius dalam proses pengajuan dana ADD kecuali adanya keterlambatan dari Pemerintah Kabupaten yang pastinya kendala tersebut juga akan dialami beberapa desa lain di Kabupaten, sehingga pelaksanaan musyawarah pembahasan pelaksanaan kegiatan juga menjadi tertunda. Berikut penjelasan Kaur Keuangan:

"kalo kendalanya yang sering terjadi itu ya molor dari Pemkabnya, jadi rapat buat ngebahas pelaksanaan kegiatan juga pasti molor. Soalnya kan rapat bisa diadakan kalau dana ADD sudah masuk rekening desa. Jadi ya bisa dipastikan desa-desa lain kendala nya juga pasti sama, karena kan dari Kabupatennya." (Kaur Keuangan Desa Panggungrejo) 
Menurut Peraturan Bupati (Perbup) Malang Nomor 35 Tahun 2017 juga dijelaskan bahwa persiapan pelaksanaan kegiatan dapat dilaksanakan setelah dana Alokasi Dana Desa (ADD) telah masuk ke dalam Rekening Kas Desa. Hal tersebut dapat disesuaikan dengan penjelasan dari Kaur Keuangan di atas, bahwa adanya keterlambatan pencairan dana akan mempengaruhi keterlambatan pelaksanaan kegiatan. Penjelasan tersebut juga dapat disesuaikan dengan Buku Kas Umum Desa Panggungrejo yang di dalamnya terdapat rincian bahwa pencairan dana ADD tahap I Desa Panggungrejo baru dapat dicairkan pada tanggal 28 Mei 2019 dan pencairan tahap II baru dilaksanakan pada tanggal 28 Agustus 2019 yang seharusnya dilakukan pada bulan Maret untuk tahap I dan bulan Juni untuk tahap II. Keterlambatan ini terjadi karena terdapat kendala yang dialami oleh Kabupaten Malang, sehingga dapat dipastikan keadaan yang sama juga akan dialami oleh desa-desa lain di Kabupaten Malang.

Dalam hal lain meskipun pencairan dana ADD terjadi keterlambatan, namun Kepala Urusan Perencanaan Desa Panggungrejo menjelaskan bahwa tahap awal dari pelaksanaan kegiatan tetap dilaksanakan rapat di desa yang dihadiri oleh unsur perangkat desa, anggota Badan Permusyawaratan Desa, Lembaga Kemasyarakatan, dan tokoh masyarakat meskipun dengan adanya pergeseran timeline.

"tahap awalnya ya pak Kades mengundang perangkat, anggota BPD, LPMD, dan tokoh masyarakat untuk menghadiri rapat yang akan membahas persiapan pelaksanaan kegiatan, jadwalnya, pembagian tupoksi, penjadwalan evaluasi dan pertemuan rutin."

(Kaur Perencanaan Desa Panggungrejo)

Hasil wawancara di atas dapat disesuaikan dengan Perbup yang menjelaskan bahwa Setelah dana ADD diterima oleh Pemerintah Desa melalui rekening desa, dapat dilaksanakan rapat persiapan pelaksanaan kegiatan oleh kepala desa dengan mengundang dan dihadiri oleh perangkat desa, anggota Badan Permusyawaratan Desa (BPD), tokoh masyarakat dan lembaga kemayarakatan untuk membahas :

1. Pelaksanaan kegiatan serta penjadwalannya,

2. Pembagian tugas untuk para pelaksana kegiatan, dan

3. Kesepakatan pelaksanaan pertemuan rutin dalam hal evaluasi pelaksanaan untuk kemudian hasil rapat dituangkan ke dalam berita acara.

Pada pelaksanaan program dan kegiatan, Pemerintah Desa Panggungrejo selalu melibatkan warga desa untuk turut berperan pada seluruh tahap dengan dibentuknya panitia lokal untuk masing-masing program yang disesuaikan dengan lokasi dilaksanakannya program dan kegiatan. Pembentukan panitia lokal tersebut dilakukan setelah dilaksanakannya rapat dalam rangka pembahasan pelaksanaan kegiatan dan penjadwalan serta pembagian tugas para pelaksana kegiatan. Meskipun dalam pelaksanaan program terdapat kendala berupa keterlambatan penyaluran dana dari Pemerintah Kabupaten Malang, hal tersebut tidak menjadi kendala utama dalam pelaksanaan program meskipun timeline pelaksanaan harus bergeser. Dalam rangka penerapan prinsip akuntabilitas, selama pelaksanaan program dan kegiatan dilakukan dokumentasi progress sejak awal sebelum kegiatan dilaksanakan, pada saat pelaksanaan, dan akhir kegiatan pelaksanaan. Beberapa hal diatas dapat disesuaikan dengan indikator pelaksanaan kegiatan yang termuat di dalam Peraturan Bupati (Perbup) Malang Nomor 35 Tahun 2017. Dengan demikian tahap pelaksanaan Alokasi Dana Desa (ADD) Pemerintah Desa Panggungrejo tetap dapat dinyatakan akuntabel karena telah berhasil mengimplementasikan prinsip akuntabilitas.

\section{Pertanggungjawaban}

Pertanggungjawaban merupakan tahapan penting yang wajib dilaksanakan di akhir pelaksanaan program dan kegiatan, dengan bentuk adanya pelaporan laporan pertanggungjawaban. Dalam pengelolaan ADD, Peraturan Bupati Malang Nomor 35 
Tahun 2017 menjelaskan bahwa pertanggungjawaban dilakukan oleh: (1) Para pelaksana kegiatan yang pertanggungjawabannya disampaikan kepada PTPKD yang selanjutnya (2) PTPKD menghimpun seluruh pertanggungjawaban dari para pelaksana kegiatan untuk kemudian disusun pertanggungajawaban yang disampaikan kepada bupati melalui camat dalam bentuk rekapitulasi kepada DPMD, (3) Kepala desa menyampaikan laporan pertanggungjawaban atas penggunaan ADD kepada DPMD melalui camat, (4) DPMD menyampaikan rekapitulasi pertanggungjawaban penggunaan ADD dari kepala desa kepada bupati.

Dalam pertanggungjawaban pengelolaan ADD, kepala desa berperan penting karena bertanggungjawab atas penggunaan dana ADD. Hasil penelitian menjelaskan pada tahap pertanggungjawaban, dilakukan dengan adanya laporan pertanggungjawaban yang disusun oleh masing-masing pelaksana kegiatan dan kepala desa. Pelaporan yang dilaksanakan oleh masing-masing pelaksana kegiatan, diserahkan kepada Pelaksana Teknis Pengelolaan Keuangan Desa (PTPKD) untuk kemudian dihimpun dan direkapitulasi ke Dinas Pemberdayaan Masyarakat dan Desa (DPMD). Sedangkan pelaporan yang dilaksanakan oleh kepala desa, diserahkan kepada DPMD melalui Camat untuk selanjutnya diserahkan kepada Bupati.

Hasil penelitian menjelaskan bahwa pertanggungjawaban pengelolaan ADD yang dilaksanakan Pemerintah Desa Panggungrejo telah mengacu pada Perbup. Hasil wawancara bersama Kepala Desa Panggungrejo mengungkapkan bahwa pertanggungjawaban pengelolaan Alokasi Dana Desa (ADD) di Desa Panggungrejo ada yang dilakukan oleh pelaksana kegiatan kepada Pelaksana Teknis Pengelolaan Keuangan Desa (PTPKD) dan ada juga yang dilaksanakan oleh Kepala Desa kepada Bupati melalui Camat.

Kepala Desa Panggungrejo juga menjelaskan bahwa sebenarnya pelaksanaan pertanggungjawaban yang dilaksanakan oleh pelaksana tugas, PTPKD, dan Kepala Desa memiliki jalur struktural yang sama, yakni pertanggungjawaban yang disampaikan kepada Bupati melalui Camat dan direkapitulasi oleh Dinas Pemberdayaan Masyarakat dan Desa (DPMD). Selama penyusunan maupun penyampaian pelaporan untuk pertanggungjawaban, Pemerintah Desa Panggungrejo tidak mengalami adanya hambatan maupun kendala dikarenakan komunikasi dua arah yang sudah terjalin dengan baik.

“....ada dua jenis yang dilaporkan, dari Kepala Desa dan PTPKD nanti untuk detailnya bisa ditanyakan kepada Kaur Perencanaan. Untuk pelaporan yang merupakan kewajiban Kepala Desa ya arahnya nanti dari Kepala Desa disampaikan kepada Camat kemudian nanti kecamatan menyampaikan kepada DPMD dan dilaporkan ke Bupati. Jadi dari desa nggak langsung ke Bupati. Untuk pelaporan alhamdulillah belum pernah ada kendala." (Kepala Desa, Desa Panggungrejo)

Kepala Urusan (Kaur) Perencanaan juga membenarkan bahwa terdapat pertanggungjawaban yang wajib dilaksanakannya selaku Pelaksana Teknis Pengelolaan Keuangan Desa (PTPKD). Beliau juga menjelaskan bahwa pertanggungjawaban yang dilaksanakan merupakan penyampaian laporan yang berisi rekapitulasi pertanggungjawaban pelaksana kegiatan untuk seluruh program dan kegiatan yang dilaksanakan.

"ada pelaporan yang berisi seluruh rekapitulasi pertanggungjawaban yang disusun oleh pelaksana kegiatan atau TPK, itu nanti dilaporkan kepada Camat untuk disampaikan kepada Bupati melalui DPMD." (Kaur Perencanaan, Desa Panggungrejo)

Kaur Perencanaan juga mengungkapkan bahwa pertanggungjawaban tersebut juga dapat disesuaikan dan dikaitkan dengan kebijakan pengelolaan keuangan desa yang menyebutkan bahwa pelaksana kegiatan bertanggungjawab atas pengeluaran yang menyebabkan adanya beban anggaran belanja kegiatan, sehingga dilakukan pencatatan ke dalam pembantu kas kegiatan sebagai pertanggungjawaban 
pelaksanaan di desa. Dengan demikian, pelaksana tugas diwajibkan melaporkan hasil pelaksanaan program dan kegiatan beserta rincian anggaran yang digunakan untuk kemudian dilakukan pengajuan Surat Permintaan Pembayaran (SPP) sebagai bentuk pertanggungjawaban yang harus dilaksanakan dan dilaporkan kepada Kepala Desa.

Kaur Keuangan menjelaskan bahwa pertanggungjawaban yang dilaksanakan oleh pelaksana kegiatan telah dilaksanakan dengan tahapan pengajuan SPP ditujukan kepada Sekretaris Desa dengan dilampiri Pernyataan Pertanggungjawaban Belanja dan lampiran Pertanggungjawaban Belanja untuk kemudian diverifikasi. Apabila SPP telah diverifikasi, SPP diserahkan kepada Kepala Desa untuk disetujui kemudian dilanjutkan dengan Bendahara melakukan pembayaran.

\begin{abstract}
“kalau selesai pelaksanaan kegiatan pakai SPP, Surat Permintaan Pembayaran. Diprosesnya kalau sudah selesai kegiatannya. Nanti siapa TPK nya mengajukan SPP ke Pak Kades dilampiri tanda bukti sama pernyataan pertanggungjawaban. Tapi itu nanti sebelum ke Pak Kades diverifikasikan dulu ke Pak Carik, baru nanti kalau udah, baru ke Pak Kades buat disetujui, nanti saya yang melakukan pembayaran sekaligus dicatat apa saja tadi pengeluarannya." (Kaur Keuangan Desa Panggungrejo)
\end{abstract}

Kaur Keuangan menyebutkan bahwa dengan demikian dapat dipastikan pertanggungjawaban masing-masing pelaksana tugas dapat terlaksana sesuai dengan regulasi yang digunakan, karena jika tidak adanya pertanggungjawaban yang dilakukan, maka dapat diketahui pada laporan realisasi pelaksanaan APBDes bahwa anggaran tidak akan terserap.

Berdasarkan hasil observasi dan hasil wawancara pada masing-masing informan dapat disesuaikan antara satu dengan yang lainnya dengan amanah yang terkandung di dalam Peraturan Bupati Malang Nomor 35 Tahun 2017. Dengan demikian Pemerintah Desa Panggungrejo telah dinyatakan akuntabel karena berhasil mengimplementasikan prinsip akuntabilitas dalam tahap pertanggungjawaban pengelolaan dana Alokasi Dana Desa.

\title{
SIMPULAN
}

Akuntabilitas pengelolaan Alokasi Dana Desa (ADD) oleh Pemerintah Desa Panggungrejo, dilaksanakan melalui 3 (tiga) tahap yakni perencanaan, pelaksanaan, dan pertanggungjawaban. Ketiga tahapan yang dilaksanakan, tidak ditemui adanya kendala yang terjadi kecuali keterlambatan penyaluran dana oleh Pemerintah Kabupaten Malang yang menyebabkan adanya pergeseran timeline pelaksanaan kegiatan. Namun hal tersebut tidak menggoyahkan komitmen Pemerintah Desa Panggungrejo untuk tetap menerapkan prinsip penggunaan dana ADD dalam rangka kesejahteraan rakyat. Pada masing-masing tahap dalam pengelolaan ADD, Pemerintah Desa Panggungrejo telah menerapkan prinsip akuntabilitas yang dibuktikan dengan kesesuaian seluruh indikator akuntabilitas menurut Peraturan Bupati Malang Nomor 35 Tahun 2017.

Penelitian ini memiliki keterbatasan dimana dalam pengukuran implementasi prinsip akuntabilitas hanya disesuaikan dengan salah satu regulasi yang digunakan. Selain itu, penelitian ini hanya membahas teknis pelaksanaan pengelolaaan Alokasi Dana Desa (ADD) serta tidak membahas secara detil pada besaran anggaran, dan masing-masing program, serta kegiatan yang saling berkaitan. Dengan demikian, saran yang dapat diberikan untuk peneliti selanjutnya adalah disarankan untuk membahas lebih detil mengenai seluruh komponen yang berkaitan dengan pengelolaan ADD sehingga dapat diketahui hasil penerapan prinsip akuntabilitas dengan lebih mendalam.

\section{DAFTAR RUJUKAN}

Andini, D. P., \& Ahmad, A. (2021). The Accountability of the Village Fund Allocation 
Management at Jenggawah Village, Jember Regency. The First International Conference on Social Science, Humanity, and Public Health (ICOSHIP 2020), 7478.

Apriliani, S. G. 2015. Akuntabilitas Pengelolaan Alokasi Dana Desa di Desa Kedungrejo Kecamatan Muncar Kabupaten Banyuwangi Tahun 2013. Skripsi, Fakultas Ekonomi.

http://repository.unej.ac.id/handle/123456789/61025.

Astuti, T. P., \& Yulianto, Y. (2016). Good Governance Pengelolaan Keuangan Desa Menyongsong Berlakunya Undang-Undang No. 6 Tahun 2014. Berkala Akuntansi Dan Keuangan Indonesia, 1(1), 1-14. https://doi.org/10.20473/baki.v1i1.1694

Elgia Astuty, Eva Hany Fanida. 2013. Akuntabilitas Pemerintah Desa Dalam Pengelolaan Anggaran Pendapatan Dan Belanja Desa (APBDes) (Studi Pada Alokasi Dana Desa Tahun Anggaran 2011 Di Desa Sareng Kecamatan Geger Kabupaten Madiun). Publika, 1(2).

Fajri, R., Setyowati, E., \& Siswidiyanto. (2015). Akuntabilitas Pemerintah Desa Pada Pengelolaan Alokasi Dana Desa (Studi Pada Kantor Desa Ketindan, Kecamatan Lawang, Kabupaten Malang). Jurnal Administrasi Publik (JAP), 3(7), 1099-1104.

Febri Arifiyanto, D., \& Kurrohman, T. (2014). Akuntabilitas Pengelolaan Alokasi Dana Desa Di Kabupaten Jember. Jurnal Riset Akuntansi Dan Keuangan, 2(3), 473. https://doi.org/10.17509/jrak.v2i3.6598

Imawan, A., Irianto, G., \& Prihatiningtias, Y. W. (2019). Peran Akuntabilitas Pemerintah Desa Dalam Membangun Kepercayaan Publik. Jurnal Akuntansi Multiparadigma, 10(1). https://doi.org/10.18202/jamal.2019.04.10009

Krina, P., Loina. 2003. Indikator dan Alat Ukur Prinsip Akuntabilitas, Transparansi, dan Partisipasi. Bappenas: Jakarta.

Laporan Realisasi Anggaran Pendapatan dan Belanja Desa Panggungrejo Tahun Anggaran 2019.

Mardiasmo. 2009. Akuntansi Sektor Publik. Penerbit Andi, Yogyakarta.

Miftahuddin. 2018. Akuntabilitas dan Transparansi Pemerintah Desa terhadap Pengelolaan Dana Desa. Skripsi. Fakultas Ekonomi. Universitas Islam Indonesia. Yogyakarta.

Nahruddin, Z. 2014. Akuntabilitas Dan Transparansi Pengelolaan Dana Alokasi Desa Di Desa Pao-Pao Kecamatan Tanete Rilau Kabupaten Barru. Otoritas : Jurnal Ilmu Pemerintahan, 4(2), 193-201.

Peraturan Bupati Malang Nomor 38 Tahun 2018 tentang Pengelolaan Keuangan Desa.

Peraturan Bupati Malang Nomor 35 Tahun 2017 tentang Pedoman Pengelolaan Alokasi Dana Desa.

Peraturan Menteri Dalam Negeri Republik Indonesia Nomor 113 Tahun 2014 tentang Pengelolaan Keuangan DesaPutra, P. A. S., Sinarwati, K., \& Wahyuni, M. A. (2017). Akuntabilitas dan Transparansi Pengelolaan Alokasi Dana Desa (ADD) di Desa Bubunan, Kecamatan Seririt, Kabupaten Buleleng. E-Journal S1 Ak Universitas Pendidikan Ganesha, 8(2), 1-11.

Putra, P. A. S., Sinarwati, K., \& Wahyuni, M. A. 2017. Akuntabilitas dan Transparansi Pengelolaan Alokasi Dana Desa (ADD) di Desa Bubunan, Kecamatan Seririt, 
Kabupaten Buleleng. E-Journal S1 Ak Universitas Pendidikan Ganesha. 8(2). 1-11.

R. Apriliana. 2017. Pengelolaan Alokasi Dana Desa dalam Mewujudkan Good Governance. Jurnal Ekonomi dan Bisnis. 3(1). 45.

Safitri, T. A., \& Fathah, R. N. 2018. Pengelolaan Alokasi Dana Desa Dalam Mewujudkan Good Governance. Jurnal Litbang Sukowati: Media Penelitian Dan Pengembangan. 2(1). 89-105.

Subroto, A. 2009. Akuntabilitas Pengelolaan Dana Desa (Studi Kasus Pengelolaan Alokasi Dana Desa Di Desa-Desa Dalam Wilayah Kecamatan Tlogomulyo Kabupaten Temanggung Tahun 2008). Program Studi Magister Sains Akuntansi Program Pasca Sarjana Universitas Diponegoro Semarang, 1-109.

Syahadatina, R. 2017. Akuntabilitas Pengelolaan Alokasi Dana Desa di DEsa Rapa Laok Kecamatan Omben Kabupaten Sampang. Jurnal AKuntansi Dan Investasi. 2(1). 1-18.

Undang-Undang Nomor 6 Tahun 2014 Tentang Desa

V. Wiratna Sujarweni. 2019. Akuntansi Desa. Pustaka Baru. Yogyakarta

Wida, S. A., Supatmoko, D., \& Kurrohman, T. 2017. Akuntabilitas Pengelolaan Alokasi Dana Desa (ADD) di Desa - Desa Kecamatan Rogojampi Kabupaten Banyuwangi. E-Journal Ekonomi Bisnis Dan Akuntansi. 4(2). 148.

Widiyanti, Arista. 2017. Akuntabilitas dan Transparansi Pengelolaan Alokasi Dana Desa (Studi pada Desa Sumberejo dan Desa Kandung di Kecamatan Winongan Kabupaten Pasuruan. Skripsi. Malang: Universitas Islam Negeri (UIN) Maulana Malik Ibrahim 